\title{
Gender, Market Participation and Household Income Differential in Nigeria: Analysis of Covariance Approach
}

\author{
Oluwole Ibikunle Ogunyemi ${ }^{1,}$,, Babajide Ayodeji Lawal ${ }^{2}$ \\ ${ }^{1}$ Agricultural Extension and Management Department, Lagos State Polytechnic, Ikorodu, Lagos, Nigeria \\ ${ }^{2}$ Assurance Group, PricewaterhouseCoopers LLP, Dallas, United States of America \\ Email address: \\ ogunyemi.o@mylaspotech.edu.ng (O. I. Ogunyemi),woleoguns@yahoo.com (O. I. Ogunyemi), babajidelawal@gmail.com (B. A. Lawal) \\ ${ }^{*}$ Corresponding author
}

To cite this article:

Oluwole Ibikunle Ogunyemi, Babajide Ayodeji Lawal. Gender, Market Participation and Household Income Differential in Nigeria: Analysis of Covariance Approach. Mathematics Letters. Vol. 5, No. 1, 2019, pp. 1-7. doi: 10.11648/j.ml.20190501.11

Received: March 15, 2019; Accepted: April 23, 2019; Published: June 12, 2019

\begin{abstract}
Despite the various economic reforms that have been implemented in Nigeria, the largest economy in Africa, average household income has been low. Some of the reforms have been on boosting farming productivity, non-farm employment and encouraging market participation of households and gender mainstreaming. Nevertheless, over $70 \%$ of Nigerians live below US $\$ 1$ per day. Many studies have been done on factors like education and age that affect household income but have not looked at the interactive effect of the variables. This paper, therefore, analysed the response of household income to gender, market participation, occupation and the effect of these variables in interactive forms on household income. The study used the 2010 Nigeria General Household Survey comprising 5,000 households out of which 4, 845 households were used for analysis upon data cleaning. The variables of interest included household per capita expenditure and demographics. Analysis of covariance with Tobit regression was applied. The results showed that household head income level have a diminishing return relationship with age but reduced with increase in household size. Income of the household heads that are male, participate in market and of non-farming occupation is higher by $\$ 16,273.03$, $\$ 35,685.17$ and $\$ 91,019.48$ than their opposite categories respectively. Male-farming have mean income lower by $\$ 23,284.91$ than the female-non farming household heads. There is need to promote gender mainstreaming in favour of female on household income. Non-farming occupation and market participation of farming households should be promoted to boost household income in Nigeria.
\end{abstract}

Keywords: Income, Household Head, Market Participation, Gender, Socioeconomic Factors, Nigeria

\section{Introduction}

Since 1986 Nigeria has been witnessing economic reforms which are targeted at boosting households' income through market participation and employment of individuals irrespective of their gender. The country's economy, though significantly agrarian with crippling real sector and growing telecom industry, recently became the largest in Africa. As reported by [1], the implementation of economic policies may make some people poor, leave some poorer and others better in income level. Household income has been consistently low in Nigeria and the size of the economy has therefore been widely criticised as not benefitting the majority.

The importance of income is clear as poverty is characterised by low income. About 52 and 61 per cent of Nigerians lived on less than US\$1 per day in 2004 and 2010 respectively, implying 39 per cent living on above US\$1 in 2010 [2]. Income is the wage earned by or paid to the giver of a factor of production. It is the price paid to householders for their productive inputs. At aggregate level, it is the total of all prices received by all households for their factors of production and by firms as their profits on current production. Income is what affects individual's consumption [3-5], however [6] define income as the money earned from work, investment or endowments of a household that is expressed in terms of some numeraire or units of account.

The principal factor affecting an individual's consumption expenditure, irrespective of the gender, is his level of income; and consumption expenditure is positively related to disposable income $[3,7]$. Disposable income is the income 
less tax deductions. Other dimensions of income are money income and real income. Money income measures a consumer's income in terms of some monetary units like so many Naira or Dollars [5] while real income is what money income can buy or the purchasing power of money income, measured by an index of price level [8].

Gender issue in socio-economic discuss has remain relevant and will continue to be relevant as its definitional role varies from culture to culture. Any time gender is mentioned, what comes to mind are the female folks, comprising women and girl. But gender relations keep changing with the development of the cultural society [9]. One reason for this is that women are still at disadvantaged position in getting the information and resources that they need to work more productivity and to improve family welfare [10]. Women are believed to have been neglected in time past and should therefore now be given relevant opportunities and information as the men to realize their full socio-economic potential without upsetting the cultural equation within their local area [11].

Gender pertains to both the female and male folks in the society. It is stated in [12] that gender is a concept that is used to describe the roles and activities of men and women that are usually defined and guided by the traditions and beliefs of particular cultural system. Gender can also be defined as the economic, political and cultural characteristics and opportunities that are related with being male or female and the differential consideration of the two sexes in terms of roles, relationship, personality traits, attributes, behaviours, value, relative power and influence [13].

Nigeria is said to have one of the lowest rates of female entrepreneurship in sub-Saharan Africa and the majority of the women are concentrated in casual, low-skilled, low paid informal sector employment [9]. According to the [9] Nigeria's 80.2 million women have worse life chances than men in both farming and non-farming communities and the socio-economic segregation against women cuts across all sectors including economic activity of market participation.

Market participation has been considered and defined by many authors including [14-20]. It is of two levels, the first being the decision of whether to sell farm output and the second level involves to what extent, in terms of quantity of total output to sell. Market and market participation are essential for rural transformation and boosting economic activities that raises income, reduces poverty and promotes commercialization of inputs and outputs $[14,21]$.

As reported in [14], there is the problem of examining the avenues of increasing rewards to agriculture through market participation which has the potential of check-mating ruralurban migration. With more individuals participating in the market of inputs and outputs, members of the households acquires human capital capacity that aids commercialization with resultant effects of increased household income and welfare. Female gender is noted to have less access to market information, training and productive resources including land, credit and of lower mobility [10, 12]. Market participation may therefore be in favour of the male in terms of decision taking and level of participation. This study draws from these considerations and definitions as it looks at the level of convergence and divergence in market participation vis-a-vis income level of men and women in Nigeria

The commercialisation households' output and factors influencing households' income level have been receiving researchers' interest in Africa. Lately, some of the studies include [14-24]. In [14, 21], it is reported that rise in households income levels positively affect market participation because more income enables households in acquiring more assets that encourage market participation. Holding of assets like labour, equipment, livestock and land, infrastructure and market information boost market participation of households [14, 18, 22]. Income sources other than crop, education, animal traction, increase in output, distance to the preferred marketing channel, extension visits and training, output price and location in peri-urban areas also boost household market participation $[15,17,18,20]$.

More so, the level of income of households is positively determined by level of formal education, size of household labour force, acreage of land use, ownership of non-farm rural enterprise and male headship of households, improvement in road infrastructure and access to market information [23]. Market participation by Households also affects their income levels positively according to $[14,16$, 21]. But none of these studies examines the interaction effect of any of these variables on household income level. In view of the foregoing, the study attempts to provide answers to the following questions: How does household income level varies with gender, market participation, occupation, age and the interaction forms of these variables? The objective of the study is to analyse income differential among farming and non-farming in relation to gender and market participation. Also, to recommend, based on empirical findings, ways of improving income level among farming and non-farming in households in Nigeria.

According to [25], the interaction effect of two independent variables and present the equation as $\mathrm{D}=\mathrm{b}_{0}+$ $b_{1} L+b_{2} F+b_{3} L F$. According to the study, a common error when testing the interaction (moderation) regression model is to include the product (LF in our example) while failing to include both of the individual components ( $\mathrm{L}$ and $\mathrm{F}$ ). Leaving out the individual components in the regression model inherently confounds the additive and multiplicative effects, producing biased and misleading results. The study claims that the simple rule is that the components of any products must always be included when testing the moderator effect, which upholds the position of [26]. The interpretation of interaction term in the stated equation was demonstrated by a rearrangement and regrouping of the terms to give $\mathrm{D}=$ $\left(b_{0}+b_{2} F\right)+\left(b_{1}+b_{3} F\right) L$, which describes the "simple" relationship between $\mathrm{L}$ and $\mathrm{D}$. That is, this equation describes the line relating the two variables for any fixed value of $\mathrm{F}$. The term in the first set of parentheses represents the intercept, and the term in the second set of parentheses 
represents the regression slope [25, 27-29].

The interesting part is that both the intercept and the slope depend on the level of F. As F changes, so too do the intercept and the slope of the relationship between $\mathrm{L}$ and $\mathrm{D}$. [30] states that because interactive relationships imply that the impact of $\mathrm{L}$ on $\mathrm{D}$ varies, depending on the level of $\mathrm{F}$, the idea of "the impact of L on D in general" is in fact a meaningless one. Also the impact of $\mathrm{F}$ on $\mathrm{D}$ varies depending on the level of F. This type of model is called Analysis of Covariance (ANCOVA) model as it contains an admixture of quantitative and qualitative variables [29].

\section{Methodology}

\subsection{Scope of the Study, Study Area and Data}

The 2010 Nigeria General Household Survey (GHS) is the source of the information. The GHS is part of the 2010 Living Standards Measurement Study - Integrated Surveys on Agriculture (LSMS-ISA) conducted by the National Bureau of Statistics of Nigeria in collaboration with the World Bank. The GHS has a panel sample consisting of 5,000 households who are a subsample of the GHS core survey of 22,000 households [31]. The survey collected data on multiple agricultural activities and household consumption. The sample of 4845 used after data cleaning is representative at the national level and provides reliable estimates of key socio-economic variables for the household heads. The data sets used include household demographics, occupation, food and non-food consumption expenditures, crop/livestock/fishery production and sales.

\subsection{Analytical Frameworks}

Analysis of covariance (ANCOVA) was adopted using Tobit regression to establish how household head income level differs along gender, occupation types, market participation and the interaction forms of the variables [30]. Ordinary Least Square (OLS) would give similar result in this circumstance as all the complete variables were included. However, Tobit regression is adopted because OLS has somehow become outdated among researchers on socioeconomic issues. The Tobit model follows $[32,33]$ and is expressed as:

$$
\begin{aligned}
& Y_{\mathrm{i}}=\beta \mathrm{X}_{\mathrm{i}}+\mu_{\mathrm{i}} \text { if } Y_{i}^{*}>0 \ldots \ldots . \mathrm{EQN} \\
& 0=\beta \mathrm{X}_{\mathrm{i}}+\mu_{\mathrm{i}} \text { if } Y_{i}^{*}<0 \ldots \ldots . \mathrm{EQN}
\end{aligned}
$$

Where,

$\mathrm{i}=1,2, \ldots, \mathrm{n}$ observation (ith observation)

$\mathrm{Y}=$ Income level, a continuous variable

$\mathrm{Y}$ is based on consumption expenditure of the households. According to [34]:

Per Capita Expenditure $(\mathrm{PCE})=\frac{\text { Total Expenditure }}{\text { Household Size }}$

$\mathrm{X}=$ Socioeconomic Variable (qualitative, quantitative or multiplicative variable)

The detail of the regression equation (3) is:

$$
Y=\alpha_{0}+\alpha_{1} X_{1}+\alpha_{2} X_{1}^{2}+\alpha_{3} X_{2}+\beta_{1} X_{3}+\beta_{2} X_{4}+\beta_{3} X_{5}+\beta_{4} X_{4} X_{1}+\beta_{5} X_{4} X_{2}+\beta_{6} X_{5} X_{1}+\beta_{7} X_{5} X_{2}+\beta_{8} X_{3} X_{4}+\beta_{9} X_{3} X_{5}+\mu_{i} \cdots . . E Q N
$$

Where,

$\mathrm{Y}=$ Income level of household (Naira $[\mathbb{N}]$ )

$\mathrm{X}_{1}=$ Age of Household Head (in years).

$\mathrm{X}_{1}{ }^{2}=$ Age Square

$\mathrm{X}_{2}=$ Household Size (number of individual in each household).

$\mathrm{X}_{3}=$ Household Head's Gender (Gender Dummy: 1 = Male, $0=$ Female).

$\mathrm{X}_{4}=$ Household head's market participation (Selling of output Dummy: $1=$ Selling, $0=$ Non Selling).

$\mathrm{X}_{5}=$ Household Head's Occupational Group Dummy

( 1 = Farming, $0=$ Non-Farming).

$\mathrm{X}_{4} \mathrm{X}_{1}, \mathrm{X}_{4} \mathrm{X}_{2}, \mathrm{X}_{5} \mathrm{X}_{1}, \mathrm{X}_{5} \mathrm{X}_{2}=$ Multiplicative variables as defined for $X_{i}$

$\mathrm{X}_{3} \mathrm{X}_{4}, \mathrm{X}_{3} \mathrm{X}_{5}=$ Interactive Multiplicative Dummies

$\alpha_{0}=$ Constant

$\alpha_{1, \ldots,} \alpha_{3}=$ Slope Coefficients.

$\beta_{1, \ldots,} \beta_{3}=$ Differential effects of the respective

dummy variable (or Differential Intercepts Coefficients).

$\beta_{4, \ldots}, \beta_{7}=$ Differential Slope Coefficients

$\beta_{8}, \beta_{9}=$ Differential effects of the interaction

dummies in multiplicative form (or Differential Slope

Coefficients).

$\mu=$ Error term.

All the beta coefficients $\left(\beta_{1}\right.$ to $\left.\beta_{3}\right)$ of $X_{3}$ to $X_{5}$ are the differential intercepts coefficients of the variables respectively. Each coefficient accounts for the difference between the average income value of the dummy variable category that receives the value of 1 and the average income value of the benchmark category, the category that receives the value of 0 which assumes the value of intercept, the constant coefficient. For instance, if $\beta_{1}$ is positive, it means that the dummy category with 1 has average income higher by that positive value than the benchmark category (category with zero) which takes the value of the constant. If the differential intercept coefficient of the dummy variable is not significant it means the value is the same with the value of the constant. The differential slope coefficient indicates the difference between the average income of a dummy variable category with 1 and the base category with 0 , given the quantitative variable it is interacted with [29].

The articles in [25-30] report the use and demonstrate the application of multiplicative interaction terms in multiple regression equation. All the variables to be multiplicatively interacted should be included individually in additive forms $[26,30]$ as the omission of any constitutive term may lead to biased estimates in multiplicative interaction models. The model provides the advantage of running single regression to account for the difference in the average income of the categories of household heads like between male and female, farming and non-farming and market participation and nonmarket participation. If alternative methods like Chow test 
were adopted, many regression equations would be required to account for the differences. The model also provides the advantage of increased explanatory power and significant level in the analysis at low cost and time.

One limitation of ANCOVA is that several authors make mistake in the interpretation of interactive terms in both linear and non-linear models [35] and the interpretation of regression coefficients is an issue about which there is much confusion in published results [25, 27]. Most authors agree that ANCOVA equation is sound statistically but difficult to interpret.

\section{Results and Discussion}

\subsection{Description of Selected Household Heads Characteristics}

Table 1 shows the summary statistics of the income age, household size, gender, market participation and occupational type of the household heads. From the table 1, the household heads had average income of $\$ 94,561.75$ as the maximum and minimum incomes were $\$ 2,094,681.00$ and $\$ 289.68$ respectively. This is an indication of high income inequality among the households; a feature of income distribution in Nigeria and Africa generally. The average age was 49.82 years. The lowest and highest ages were 15 and 110 years. In Nigeria, especially in the farming communities, one can see men as young as 15 years having their farm lands for either market or non-market oriented production. Such young men may even get married with children before they reach 18 years in age. Women are not left out. There could be young women that got married early in their teens, as is the case in some cultures. Such women could be household heads with farm lands, if their husbands had died within a short period of their marriage.

The average household size was approximately 6; with maximum of 31 and minimum of 1 . Large household size is highly possible in the country as some male household heads can have more than one wife with many children. By gender, 85.24 per cent of the household heads were male and 14.76 per cent were female. 26.83 per cent sold their farm products thereby participated in market while 73.17 per cent did not participate in farm product market. Occupationally, 47.97 and 52.03 per cents were into farming and non-farming respectively.

Table 1. Summary statistics of household head income, age, household size, gender, market participation and occupation.

\begin{tabular}{lll}
\hline Variable & Mean & Maximum \\
\hline Income (Naira) & $94,561.75$ & $2,094,681.00$ \\
Age (Years) & 49.82 & 110 \\
Household size & 5.78 & 31 \\
Gender: Frequency (\%) & Male: $4,130(85.24 \%)$ & Female: $715(14.76 \%)$ \\
Market Participation: Frequency (\%) & Participation: $1,300(26.83 \%)$ & 15 \\
Occupation: Frequency (\%) & Farming: $2,324(47.97 \%)$ & Non-participation: 3, 545 (73.17\%) \\
\hline
\end{tabular}

Source: Stata analysis of data obtained from 2010 Nigeria General Household Survey.

\subsection{Effect of Age, Gender, Household Size, Market Participation, Occupation and Their Interactions on Income}

The details of the regression results are shown in Table 2. The diagnostic features of the regression results show that it is a good fit with probability chi-square of 0.00 with 4,845 observations. There was no censoring as all the observations were captured for the analysis. All the coefficients of the variables in the regression model, except that of age $\left(\mathrm{X}_{1}\right)$, are significant at $10 \%$ level. Precisely, household size and occupation were significant at 1 per cent level while gender and market participation were significant at 5 per cent level. All the coefficients of the co-variables, in interactive form, are significant.

Though age is not significant, the positive sign of the coefficient shows that as age of a household head increases, his income (Y) increases but at a decreasing rate evidenced from the negative sign of the coefficient of age square $\left(\mathrm{X}_{1}{ }^{2}\right)$. This means that income will get to a peak with age increase and then start to decline in the pattern of diminishing return curve. However, 1 unit increase in household size $\left(X_{2}\right)$ leads to $\$ 15,513.68$ reduction in household income. The average income of male household heads $\left(\mathrm{X}_{3}\right)$ is significantly different from that of and higher by $¥ 16,273.03$ than the female household heads. If the females take the value of the constant ( $\$ 180,531.20)$ as their average income, the average income of the male is the sum of $\$ 16,273.03$ and $\$ 180$, 531.20 which is $\$ 196,804.23$. The implication of this is that the female is lagging behind in terms of

Table 2. Tobit regression of effect of age, gender, household size, occupation and their interactions on income.

\begin{tabular}{|c|c|c|c|c|c|c|}
\hline Household Head's Income & Coefficient & Standard Error & t-value & $\mathbf{P}>/ \mathbf{t} /$ & \multicolumn{2}{|c|}{ [95\% Confidence Interval] } \\
\hline Age $\left(\mathrm{X}_{1}\right)$ & 584.79 & 532.79 & 1.10 & 0.272 & -459.72 & $1,629.30$ \\
\hline Age square $\left(\mathrm{X}_{1}^{2}\right)$ & -8.36 & 4.85 & -1.72 & 0.085 & -17.87 & 1.14 \\
\hline Household size $\left(\mathrm{X}_{2}\right)$ & $-15,513.68$ & 721.23 & -21.51 & $0.000 *$ & $-16,927.62$ & $-14,099.74$ \\
\hline $\operatorname{Gender}\left(\mathrm{X}_{3}\right)$ & $16,273.03$ & $6,176.93$ & 2.63 & $0.008 * *$ & $4,163.43$ & $28,382.63$ \\
\hline Market participation $\left(\mathrm{X}_{4}\right)$ & $35,685.17$ & $14,375.49$ & 2.48 & $0.013 * *$ & $7,502.68$ & $63,867.66$ \\
\hline Occupation $\left(\mathrm{X}_{5}\right)$ & $-91,019.48$ & $13,095.27$ & -6.95 & $0.000 *$ & $-116,692.20$ & $-65,346.79$ \\
\hline Market participation age $\left(\mathrm{X}_{4} \mathrm{X}_{1}\right)$ & -669.04 & 204.06 & -3.28 & $0.001 *$ & $-1,069.10$ & -268.98 \\
\hline
\end{tabular}




\begin{tabular}{|c|c|c|c|c|c|c|}
\hline Household Head's Income & Coefficient & Standard Error & t-value & $\mathbf{P}>/ \mathbf{t} /$ & \multicolumn{2}{|c|}{ [95\% Confidence Interval] } \\
\hline Market participation household size $\left(\mathrm{X}_{4} \mathrm{X}_{2}\right)$ & $-2,275.60$ & $1,032.69$ & -2.20 & $0.028 * * *$ & $-4,300.15$ & -251.05 \\
\hline Occupation age $\left(\mathrm{X}_{5} \mathrm{X}_{1}\right)$ & 421.92 & 182.19 & 2.32 & $0.021 * *$ & 64.74 & 779.09 \\
\hline Occupation household size $\left(\mathrm{X}_{5} \mathrm{X}_{2}\right)$ & $8,254.26$ & 913.50 & 9.04 & $0.000 *$ & $6,463.40$ & $10,045.13$ \\
\hline Gender market participation $\left(\mathrm{X}_{3} \mathrm{X}_{4}\right)$ & $23,908.22$ & $9,153.62$ & 2.61 & $0.009 * *$ & $5,962.95$ & $41,853.49$ \\
\hline Gender occupation $\left(\mathrm{X}_{3} \mathrm{X}_{5}\right)$ & $-23,284.91$ & $8,349.41$ & -2.79 & $0.005 * *$ & $-39,653.55$ & $-6,916.27$ \\
\hline Constant & $180,531.20$ & $15,166.47$ & 11.90 & 0.000 & $150,798.00$ & $210,264.40$ \\
\hline
\end{tabular}

No. of Observation $=4,845$ LR Chi square $(12)=1,048.00$ Prob $>$ chi square $=0.0000$.

Log Likelihood $=-62431.43$ Pseudo R-Square $=0.0083$ Uncensored observation $=4,845$

* Significant at $1 \% * *$ Significant at $5 \% * * *$ Significant at $10 \%$.

Source: Stata regression analysis of data obtained from 2010 Nigeria General Household Survey income in 2010 and supports [23] that male households heads have higher income than the female household heads. Households that participate in market $\left(\mathrm{X}_{4}\right)$ have average income that is significantly higher by $¥ 35,685.17$ than households that do not sell part of their produce (that do not participate in market). This implies that market participation boosts household income and compares favourably with $[16,21]$ that market participation favours income level of household heads. But household heads that are of farming occupation $\left(\mathrm{X}_{5}\right)$ have mean income significantly lower by $\$ 91,019.48$ than non-farming households. This is not a surprise, as most farming households in Nigeria are in the rural area with low productivity and high poverty level. $[15,18]$ similarly report that non-farming income sources increase the level of household head's income.

Explicitly, Tobit regression equation for factors and covariables affecting income levels of household heads can thus be expressed as:

$$
\begin{array}{r}
Y=180531.20+584.79 X_{1}-8.36 X_{1}^{2}-15513.68 X_{2}+16273.03 X_{3}+35685.17 X_{4}-91019.48 X_{5}-669.04 X_{4} X_{1}-2275.6 X_{4} X_{2}+ \\
421.92 X_{5} X_{1}+8254.27 X_{5} X_{2}+23908.22 X_{3} X_{4}-23284.91 X_{3} X_{5} \ldots \ldots \ldots \ldots . E Q N
\end{array}
$$

Recall from equation 3 that $\mathrm{X}_{1}=$ Age; $\mathrm{X}_{1}{ }^{2}=$ Age Square;

$\mathrm{X}_{2}=$ Household size; $\mathrm{X}_{3}=$ Gender;

$\mathrm{X}_{4}=$ Market participation; $\mathrm{X}_{5}=$ Occupation

The rate of change of income of market participating households with respect to age $\left(\mathrm{X}_{4} \mathrm{X}_{1}\right)$ is $\$ 669.04$ lower than the market non-participating households. This means that household income response less to age for market participating than non-participating household heads. But the rate of change of income with respect to change in household size given market participating households $\left(\mathrm{X}_{4} \mathrm{X}_{2}\right)$ is lower by $¥ 2,275.60$ than the market non-participating households. If household size increases, the negative effect, going by the coefficient of $\mathrm{X}_{2}$, on income will be less for market participating than non-participating household heads. The rate of change of income in response to change in age given occupation $\left(\mathrm{X}_{5} \mathrm{X}_{1}\right)$, is higher by $\$ 421.92$ for farming households than non-farming households. Also, the rate of change of income in response to change in household size in relation to occupation is $\$ 8,254.27$ higher for farming households than non-farming households. This implies that the effects of age and household size on income are more for farming than non-farming households heads.

Moreover for covariates that are dummies, the average income of male household heads that participate in market $\left(\mathrm{X}_{3} \mathrm{X}_{4}\right)$ is $\$ 23,908.22$ higher than that of the female household heads that are market non-participants. But the male-farming household heads $\left(\mathrm{X}_{3} \mathrm{X}_{5}\right)$ have average income lower by $\$ 23,284.91$ than the female-non farming households heads. This further supports that market participation and non-farming occupation boosts households income.

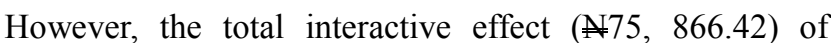
being a male-market participant achieved by adding 16 , $273.03,35,685.17$ and $23,908.22$, the coefficients of $X_{3}, X_{4}$ and $\mathrm{X}_{3} \mathrm{X}_{4}$ respectively, shows that male-market participating household heads have mean income higher by $\$ 75,866.42$ than the male household heads, market participating household heads or female-non market participating household heads, if considered distinctively groups as stated. Similarly, male-farming households $\left(\mathrm{X}_{3} \mathrm{X}_{5}\right)$ total interactive effect shows that they have mean income lower by $\$ 98$, 031.36 (addition of the coefficients of $X_{3}, X_{5}$ and $X_{3} X_{5}$; $\$ 16$, 273.03, - $\$ 1,019.48$ and - $\$ 23,284.91$ respectively) than male, farming or female-non farming household heads. These imply that market participation and non-farming occupation promote household income.

\section{Conclusions}

Income of household heads in Nigeria varies positively with age but follows the diminishing return principle and decrease with increase in household size. Male household heads, non-farming and market participating households have different and higher income than their opposite categories. Market participating have income levels higher than nonparticipating household heads with increase in age and household size. Similarly, the incomes of non-farming and market participating are impaired less than farming and market non-participating households by increase in age and household size. Non-farming occupation and market participation of farming households need to be encouraged in Nigeria to boost household income. While the female should be given attention in income boosting strategies, the male should however not be left disadvantaged. Through market oriented agriculture that involves all farming and nonfarming households without the male or female lagging behind the other, there would be higher household income. Higher household income will boost consumption and 
production and the size of the Nigeria economy would further be promoted.

\section{References}

[1] B. E. Aigbokhan (2000). Poverty, growth and in-equality in Nigeria: a case study. African Economic Research Consortium, Nairobi, AERC Research paper 102. Pp. 143.

[2] National Bureau of Statistics (2012). The Nigeria poverty profile 2010 report. NBS press briefing on Nigeria poverty profile $2010 \quad$ report. reliefweb.int/sites/reliefweb.int/files/resources $\quad / b 410$. Accessed 3 March 2012.

[3] J. C. Anyanwu and H. E. Oaikhenam (1995). Modern macroeconomics: Theory and application in Nigeria. 1st edition. Onitsha, Nigeria. Joanee Educational Publishers Ltd. Pp 50-75. ISBN: 978-2784-16-8.

[4] J. K. Olayemi (2004). Principles of microeconomics: for applied economic analysis. 1st Edition. Ibadan, Nigeria. SICO Publishers. ISBN 978-006-432-X.

[5] R. G. Lipsey and K. A. Chrystal (2005). Economics. 10th Edition. New York. Oxford University Press Inc. Pp 117-248.

[6] H. Gravelle and R. Rees (2004). Microeconomics. 3rd Edition. Harlow Essex, England. Pearson Education Limited. Prentice Hall Financial Times. Pp 4-5. ISBN 0 582404878 .

[7] E. V. Bowden (1986). Economics: the science of common sense. 1st Edition. Cincinnati, Ohio. South-Western Publishing Co. Pp 82-627. ISBN: 0-538-08980-6.

[8] A. J. Adegeye and J. S. Ditto (1985). Essentials of agricultural economics. 1st Edition. Ibadan, Nigeria. Impact Publishers Nig. Ltd. Pp 16-17. ISBN 978-2386-00-6.

[9] British Council Nigeria (2012). Improving the lives of girls and women in Nigeria: Issues Policies Action. Gender in Nigeria report 2012, $2^{\text {nd }}$ edition. http://www.dfid.gov.uk/Documents/publications1/GenderNigeria 2012.pdf. Accessed 10 October 2012.

[10] O. O. Herz (1989) Rural urban migration in Africa. Journal of Farm Economics Vol. 9.1.

[11] E. B. I. Ononiwu (2002). Newsletter to Poverty Alleviation in Nigeria. The Dimensions of Poverty in Nigeria (spatial sectoral, Gender et al). Vol. 23.4 pg 17, Published by Central Bank of Nigeria.

[12] L. Buckland and J. Haleegoah (1996). Gender analysis in agricultural production. IITA Research Guide 58. Training Programme, International Institute of Tropical Agriculture (IITA). Ibadan, Nigeria. 24 p.

[13] United State Agency for International Development (2006). Pro-poor growth, gender, and markets: Creating opportunities and measuring results. http://www.wemanresources.info/documents/Page3_GenderM ainstreaming/3_3_Markets/GenderMarkets_USAID2006.pdf. Accessed 22 July 2013.

[14] D. Boughton, D. Mather, C. B. Barrett, R. Benfica, D. Abdula, D. Tschirley and B. Cunguara (2007). Market Participation by Rural Households in a Low-Income Country: An Asset-Based
Approach Applied to Mozambique. Faith and Economics Vol. 50: 64-101.

[15] S. T. Bahta and S. Bauer (2007). Analysis of the determinants of market participation within the South African small-scale livestock sector. Tropentag paper Witzenhausen.

[16] M. Mathenge, F. Place, J. Olwande and D. Mithoefer (2010). Participation in agricultural markets among the poor and marginalized: analysis of factors influencing participation and impacts on income and poverty in Kenya. Study report, Jul. www.tegemeo.org/. Accessed 15 July 2013.

[17] N. Chilundika (2011). Market participation of bean smallholder farmers in Zambia: a gender based approach. A Research Report presented to the Department of Agricultural Economics and Extension Education of the University of Zambia Bachelor's Degree Project Unpublished. http://valuechains.k-state.edu/Natasha\%20Chilundika.pdf. Accessed 24 July 2013.

[18] B. S. Gani and A. I. Adeoti (2011). Analysis of market participation and rural poverty among farmers in northern part of Taraba State, Nigeria. Journal of Economics, 2 (1): 23-36.

[19] Md. S. Azam, K. S. Imai, and R. Gaiha (2012). Agricultural supply response and smallholders market participation - the case of Campodia. Research Institute of Economics and Business Administration. Discussion paper No. DP2012-09. www.rieb.kobe- u.ac.jp/academic/ra/dp/English/DP201209.pdf. Accessed 15 July 2013.

[20] A. O. Onoja, B. B. Usoroh, D. T. Adieme, and N. J. Deedam (2012). Determinants of market participation in Nigerian small-scale fishery sector: evidence from Niger Delta Region. The Journal of Sustainable Development Vol. 9, Iss. 1: Pp. 6984.

[21] T. Reardon and C. P. Timmer (2005). Transformation of markets for agricultural output in developing countries since 1950: how has thinking changed? Chapter 13 in R. E. Evenson, P. Pingali, and T. P. Schultz (editors). (2005). Volume 3 Handbook of Agricultural Economics: Agricultural Development: Farmers, Farm Production and Farm Markets. Jul.

siteresources.worldbank.org/...1150389437293/Reardon_Tim mer. Accessed 24 July 2013.

[22] J. M. Omiti, D. J. Otieno, T. O. Nyanamba and E. McCullough (2009). Factors influencing the intensity of market participation by smallholder farmers: A case study of rural and peri-urban areas of Kenya. The African Journal of Agricultural and Resource Economics (AfJARE) Vol. 3. No. 1. Mar.

[23] J. Aikaeli (2010). Determinants of rural Income in Tanzania: An empirical approach. Research on Poverty Alleviation (REPOA). Research report 10/4. http://www.repoa.or.tz/documents/rr10_4.pdf. Accessed 15 July 2013. October 9-11. www.tropentag.de/2007/abstracts/full/422.pd. Accessed 25 July 2013.

[24] R. V. Hill and M. Vigneri (2011). Mainstreaming gender sensitivity in cash crop market supply chains. Agricultural Development Economics Division, Food and Agriculture Organisation of the United Nations. ESA Working Paper No. 11-08 Mar. http://www.fao.org/docrep/013/am313e/am313e00.pdf. Accessed 13 July 2013. 
[25] M. A. Whisman and G. H. McClelland (2005). Designing, testing, and interpreting interactions and moderator effects in family research. Journal of Family Psychology, Vol. 19.1: 111-120. wwwpsychology.concordia.ca/fac/kline/734/whisman.pdf. Accessed 30 January 2012.

[26] T. Brambor, W. R. Clark and M. Golder (2005). Understanding interaction models: Improving empirical analyses. Political Analysis, 13: 120 doi: 10.1093/pan/mpi014. Political Analysis Advance Access published May 18. http://www.fsu.edu. Accessed 30 January 2012.

[27] R. J. Friedrich (1982). In defence of multiplicative terms in multiple regression equations. American Journal of Political Science, $\quad$ Vol. 26.4: 797-833. http://www.jstor.org/stable/2110973. Accessed 13 January 2012.

[28] L. Hargens (2006). Interpreting product-variable models of interaction effects. Working Paper no. 67. Center for Statistics and the Social Sciences. University of Washington, Seattle. Nov 8. Revised Feb 2008. www.csss.washington.edu/Papers. Accessed 30 January 2012.

[29] D. N. Gujarati and D. C. Porter (2009). Basic econometrics. 5th edition. McGraw-Hill, New York. Pp 277-290, 574-576. ISBN: 978-007-127625-2.

[30] B. F. Braumoeller (2004). Hypothesis testing and multiplicative interaction terms. Harvard University,
Department of Government, Littauer Center, North Yard Cambridge. www.cc.rochester.edu/ college/psc/ clarke/405/Braumoeller.pdf. Accessed 31 January 2012.

[31] World Bank (2013). Living Standards Measurement Survey Integrated Survey on Agriculture. Development Research, World Bank, Wasington D. C. http://go.worldbank.org/EVYKSFZJ50. Accessed 5 August 2013.

[32] J. F. McDonald and R. A. Moffitt (1980). The uses of Tobit analysis. Review of Economics and Statistics, 62: 318-321.

[33] B. T. Omonona, O. A. Oni and A. O. Uwagboe (2006). Adoption of improved cassava varieties and its welfare impact on rural farming households in Edo State, Nigeria. Journal of Agriculture and Food Information, Vol. 7.1: 39-55. The Haworth Information Press. ISSN: 1049-6505.

[34] National Bureau of Statistics (2005). Poverty profile in Nigeria. NBS. Abuja, Nigeria. Pp 1-98. Retrieved Aug. 27, 2007 from www.nigerianstat.gov.ng/ nlss/2006/survey0 /output Information/prereport.pdf.

[35] E. C. Norton, H. Wang and C. Ai (2004). Computing interaction effects and standard errors in logit and probit models. The Stata Journal, Vol. 4.2: 154-167. www.ageconsearch.umn.edu. Accessed 12 August 2012. 